JOAL, (JOURNAL OF APPIIII) LINGUISTIICS ANI) LITIRA'TURE)

Vol. 4 No. 2, 2019

ISSN (print): 2502-7816; ISSN (online): 2503-524X

Available online at https:/ / ejournal.unib.ac.id/index.php/joall/index doi: http://dx.doi.org/10.33369/joall.v4i2.7759

\title{
FOREIGNIZATION AND DOMESTICATION IN THE MINISTERIAL WEBSITE LOCALIZATION
}

\author{
Ely Hayati Nasution'; Roswita Silalahi2; Vivi Adryani Nasution ${ }^{3}$
}

\author{
Department of English, Faculty of Cultural Sciences, Universitas Sumatera Utara, \\ Medan, Indonesia ${ }^{1,2}$ \\ Department of Mandarin Language, Faculty of Cultural Sciences, Universitas \\ Sumatera Utara, Medan, Indonesia ${ }^{3}$
}

Corresponding email: ely@usu.ac.id

\begin{abstract}
The translation is a representation of the effect of developing technology on language. Translated website or website localization with the easiness of accessibility is considered as the most efficient space for transferring the information nowadays. It certainly involves the appropriate translation strategies in order to provide reliable information required. This research aims to identify the translation strategy involved under foreignization and domestication reference in the official website localization of Ministry of Health of Republic of Indonesia, to find out the most dominant translation strategy used, and to analyze the reasons to what extent foreignization and domestication applied, by referring the classifications proposed by Venuti (2008). The source of data was taken from five (5) popular news along 2018 which were broken down into 191 data analyzed, consisting of 5 headlines in the form of phrases and sentences, contents totally written in 161 sentences, and 25 sub-contents in the form of words, phrases, clauses, and sentences. The research found that the translator used all eight (8) translation strategies under domestication and foreignization reference including literal translation, transliteration, borrowing, transference, transposition, omission, addition, and adaptation, simultaneously or separately. Literal translation becomes the most dominant translation strategy used and it can indicate that the website localization is translated into source text-oriented.
\end{abstract}

Keywords: domestication, foreignization, website localization, ministry of health 


\section{INTRODUCTION}

The translation is one of the representations of massive globalization and developing technology on language. The language itself generally has been recognized as the most familiar system used for communication. The existence of translation enables and widens the transfer of knowledge and information all over the world and also affects the development of other fields since the knowledge and information required are provided in the target language. Many texts have been translated for different human's purposes; engineering, agriculture, law, education, economics, politics, health, and others. The translated texts then are produced, distributed and spread in varied forms; books, leaflets, papers, newspaper, magazines, catalogs, or even websites.

Translated website or website localization is seemingly considered as the most efficient form for transferring the information as it has easiness in accessibility. People can obtain information anywhere and anytime through the availability of an internet connection. It indicates that the translated website or specifically known as website localization nowadays has become the most preferable and applicable medium and it will certainly continue to the future due to everlasting inventions on technology, especially those supporting the translation development.

The website localization which integrates translation and technology via website communication has introduced a new face in the translation space. It offers challenges to translators and translation studies. With web as its object, a new dimensional type of multimedia source material and the translation of web material constitutes a new type of multilingual service (Sandrini, 2005). This multilingual service has provenly been used for certain purposes, either for internationalization (Gutiérrez-Artacho \& Olvera-Lobo, 2017) or promotion (Obeidat, E. \& Abu-Melhim, 2017; Sitohang, 2019; Valdés, 2014). In order to reach that certain purpose, two constituent elements of translation, namely translating and adapting must become the priority for the translation as the degree of translating and adapting will vary, according to the scope of the website localization and the readers involved. Thus, a translator must be able to specify the appropriate translation strategies because it will affect the reader's ability to understand the information presented in the translated or localized website. Translators are basically faced with two main problems, firstly on how to treat the certain aspects implicitly conveyed in a source text (ST), and secondly on how to apply the most appropriate strategy of successfully conveying these aspects in the target language (TL).

There has long been a hot debate over the proper translation strategies chosen for the translating and adapting of website localization contents, and foreignization and domestication have been the focus of debate since their appearance. They become two kinds of completely 
contradictive manners of translation strategies postulated by Venuti (1995) in which the foreignized translation is source language-oriented, while the domesticated translation is target language oriented (Cui, 2011; Yang, 2014). The foreignization covers literal translation, transliteration, borrowing, and transference as the translation strategies applied; while domestication includes transposition, omission, addition, and adaptation (Venuti, 2008).

Further, there are many reasons related to this controversy. On one side, these two translation strategies are viewed as the extension of the debate on 'free translation' and 'literal translation' (Wang, 2014). On another side, maintaining the style and the flavor of the original work as far as possible to be understood and accepted by the readers becomes a challenging or even a complicated task a translator may face. Therefore, foreignization for some people may be better, but simultaneously other people thought that domestication is more appropriate (Baawaidhan, 2016; Yang, 2014). Based on these two representative reasons, it can be implied that a translator has to decide whether he will have an orientation towards the target reader or maintain the source text with its various aspects. The choice, of course, has its own consequence, hence the translator should choose the smallest risk (Prasetyo \& Nugroho, 2013) as the translation strategy chosen by the translator intentionally or unintentionally will affect the translation quality produced (Nasution, 2015).

The website localization as one of the new linguistic scopes in Indonesia has taken significant attention, for example, the localization of the ministerial website. It is commonly known that a ministry plays a continual role in order to provide the people with the relevant and newest information and issues happening recently. The website localization (WL) of the Ministry of Health $(\mathrm{MH})$ of the Republic of Indonesia (RI) is a proof of translation development not only in Indonesia but also in the world. Based on the information explored in the official website of $\mathrm{MH}$, this website localization was launched firstly in 2006 and presented in two languages, Indonesian Language (IND) as the source language (SL) and English (ENG) as the target language (TL). It contains various topics dealing with recent health matters in Indonesia. It is quite interesting to make this website as the object of this research since Indonesia is well-known as one of the tropical countries with distinctive health features compared with other tropical countries in the world; although health problems still take high portion in Indonesia to be overcome.

\section{METHODS}

There were 3 (three) main objectives of conducting this research. Firstly, identifying the translation strategies involved in the website localization of Ministry of Health translated from the Indonesian language into English 
with special reference to foreignization and domestication. Secondly, finding out the most dominant strategy used, and lastly analyzing the reasons to what extent the foreignization and domestication applied in the website localization of Ministry of Health. Official website of the Ministry of Health of the Republic of Indonesia accessed from http://www.kemkes.go.id/ became the main source of data for this research. In addition, all translated news released in 2008 and retrieved from the website was selected as the population of the research, yet only five (5) of them categorized as the most popular news along 2018 with the translated versions were selected as the sample of the research in order to find out the translation strategies as well as the most dominant strategy used under foreignization and domestication classifications proposed by Venuti (2008).

Although the sample seems little, it represents a rich and vivid example of significant health issues released by the Ministry of Health of the Republic of Indonesia along 2018. All the words, phrases, clauses, or sentences contained foreignization and domestication were treated as the primary data, then they were used to describe the reasons of underlying the using of those strategies in the website localization of Ministry of Health of the Republic of Indonesia.

\section{FINDINGS}

\section{Translation Strategies Used in the Website Localization of Ministry of Health of Republic of Indonesia}

Based on the result of analysis on five (5) popular news along 2018 in the website localization of Ministry of Health of Republic of Indonesia which were broken down into 191 data analyzed, consisting of 5 headlines in the form of phrases and sentences, contents totally written in 161 sentences, and 25 sub-contents in the form of phrases, clauses and sentences, it was found that the translator used all eight (8) translation strategies under foreignization and domestication reference including literal translation, transliteration, borrowing, transference, transposition, omission, addition, and adaptation, as shown in table 1.

Table: 1 The percentage of the translation strategies used in the website localization of Ministry of Health of the Republic of Indonesia

\begin{tabular}{lcclcc}
\hline \multicolumn{1}{c}{ Foreignization } & Number & Percentage & Domestication & Number & Percentage \\
\hline Literal Translation & 135 & 70.68 & Transposition & 70 & 36.37 \\
Transliteration & 79 & 41.36 & Omission & 37 & 19.37 \\
Borrowing & 63 & 32.98 & Addition & 16 & 8.38 \\
Transference & 38 & 19.90 & Adaptation & 9 & 4.71 \\
\hline
\end{tabular}

The result of data analysis displayed in table 1 shows that both domestication and foreignization were used in the website localization and 
the highest percentage of literal translation among other translation strategies used indicates that foreignization is dominantly used in the website localization of Ministry of Health of Republic of Indonesia, as seen in table 2.

Table: 2 The percentage of domestication and foreignization used in the website localization of Ministry of Health of the Republic of Indonesia

\begin{tabular}{clcc}
\hline No. & Translation Strategies & Number & Percentage \\
\hline 1 & Domestication & 166 & 86.91 \\
2 & Foreignization & 106 & 55.50 \\
\hline
\end{tabular}

Both domestication and foreignization are often used or occur simultaneously in the headlines, contents, or sub-contents and in the form of a phrase, a clause or in a sentence, thus the total number or percentage of each translation strategy referring to domestication and foreignization is varied.

The Reasons for the Using of Foreignization and Domestication in the Website Localization of Ministry of Health of Republic of Indonesia

The highest percentage of the using of foreignization in the website localization of Ministry of Health of the Republic of Indonesia notes that domestication less attracts the attention of the translator to translate the five most popular news selected as the sample of the data in the oriented target language. The translator prefers to maintain the source text, especially in the translation of the contents of the news, which can indicate that the translator still accentuates the ability of the readers of the source language to understand the translated news found in the website localization despite the news provided in the readers' source language.

It also means that the translator has a perception that the target readers of this website commonly comes from the readers with the same source language so that the selected news are still translated with source language oriented. Whether the translation quality of this website fulfills the criteria required in the Translation Quality Assessment (TQA), the advantages and disadvantages may occur due to foreignization and domestication applied, what ideology is conveyed, will be analyzed by the researchers themselves in the further research.

\section{DISCUSSION}

The results of the data analysis presented in the former findings inform that all translation strategies under foreignization and domestication reference are used in the website localization of Ministry of Health of the Republic of Indonesia. There are four translation strategies under foreignization reference used, they are literal translation, transliteration, borrowing, and transference, and there are also four translation strategies under 
domestication reference involved, they are transposition, omission, addition, and adaptation. Both foreignization and domestication are often used simultaneously either in translating sentences, clauses or phrases, as shown in table 3.

Table: 3 The example of translation strategies used in the website localization of Ministry of Health of the Republic of Indonesia

\begin{tabular}{|c|c|}
\hline Source Text (IND) & Target Text (ENG) \\
\hline Sama seperti penyakit kronis lainnya seperti & diseases such as \\
\hline 3 & 125 \\
\hline hipertensi, kolesterol, atau DM, obat ARV & hypertension, cholesterol, or diabetes, \\
\hline $9 \overline{10}$ & 10 \\
\hline harus diminum secara teratur, tepat waktu & ARV drugs must be taken regularly, \\
\hline 16 & 11 \\
\hline dan seumur hidup, untuk meningkatkan & on time and for life, to improve the \\
\hline 18 & $\overline{16} \overline{17} \overline{18} \overline{19} \overline{20} \quad \overline{21}$ \\
\hline kualitas hidup ODHA serta dapat mencegah & quality of life for $O D H A$ and can prevent \\
\hline $\begin{array}{l}23 \\
\frac{24}{29}\end{array}$ & $\begin{array}{c}23 \\
\text { transmission. } \\
29\end{array}$ \\
\hline
\end{tabular}

The example presented in table 3 tells that there are some translation strategies used to translate a sentence taken from the contents of the news of WL of MH of RI, they are literal translation, transliteration, borrowing, transference, transposition, addition, and omission. Separately, the description of each translation strategy used together with its examples is provided in table 3 can be seen in table 4 .

Table: 4 The examples of the use of translation strategies

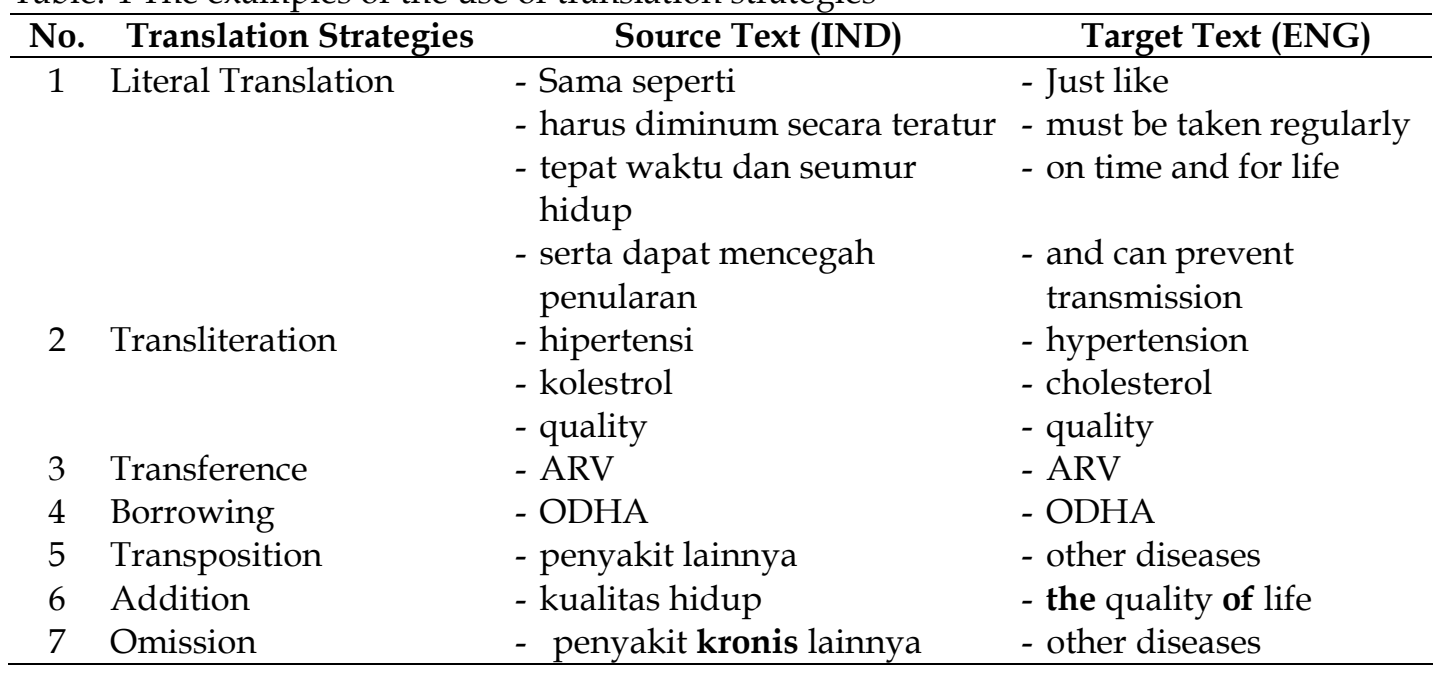

Translation Strategies of Foreignization

Literal Translation 
The literal translation is one of the translation strategies under foreignization reference means that the denotative meaning of words is taken as if it straight from the dictionary (that is, out of context), but the grammar is respected (Dickins, Hervey \& Higgin, 2002). The examples given for literal translation are in the form of clauses and phrases. The clause harus diminum secara teratur (IND) is translated into 'must be taken regularly' (ENG) and the clause serta dapat mencegah penularan is translated into 'and can prevent transmission', meanwhile the phrase tepat waktu dan seumur hidup is translated into 'on time and for life'. All examples are translated literally (word by word) as shown on the numbered words in table 3.

The literal translation used by the translator in translating the former clauses and phrase indicates that the translator tries to maintain the meaning of words of the source language. The use of this translation strategy is considered effective in the given examples because the original message is not deviated from normal usage. Moreover, Source Text (ST) and Target Text (TT) seemingly compatible in terms of meaning. No ambiguity or perplexity occurs due to the fact that each word has its own appropriate target equivalence.

\section{Transliteration}

Transliteration is another translation strategy of foreignization (a sourceoriented strategy) that focuses on the 'process of representing words from one language using the approximate phonetic or spelling equivalents of another language (as cited in Tiedemann and Nabende, 2009). The examples of transliteration strategy given in table 4 are problematic as the words hipertensi, kolesterol, and kualitas originally derive from English words 'hypertension, cholesterol, and quality'. Since the SL is the Indonesian language, when translating these words, the translator seemingly only tries to find out or to represent the equivalent spelling of these words in the TL. In other words, the SL letters are only substituted by the TL phonological units. This strategy is appropriate as there are no equivalent words available for those foreign terms, and the translator finds it inevitable to rely on transliteration.

\section{Transference}

Transference is also another translation strategy of foreignization. It is the process of directly transferring a source language word to a target language text unchanged to create some particular stylistic effect (Obeidat, 2015). The word $A R V$, for example, is transferred directly from ST into TT without any changes. ARV (antiretroviral) is a specialized medicine for HIV AIDS patients. The use of this translation strategy by the translator is considered 
acceptable as there is information stating about this previously, so the intended message can be communicated well.

\section{Borrowing}

Borrowing is the last translation strategy of foreignization used in the translation of the sentence displayed in table 3. According to Molina and Albir (2002), borrowing or translating using loan words is to take a word or expression straight from another language. Borrowing strategy in the given example is used to translate the word ODHA in ST into ODHA in TT, too. The word ODHA is basically an Indonesian language abbreviation combining Indonesian Language, OD stands for Orang Dengan (The People with) and English, HA stands for HIV AIDS. Since the term HIV AIDS has been familiar with Indonesian people, this borrowed word is commonly used and accepted. The translator in this case straightly takes the word ODHA which has become Indonesian language abbreviation into English.

\section{Translation Strategies of Domestication Transposition}

Transposition is initially introduced by Catford (1965) which is popularly called as 'shift'. Transposition is a change of one part of speech for another without changing the sense (Munday, 2001). The phrases penyakit lainnya (Noun-Adjective) in ST is translated into 'other diseases' (Adjective-Noun) in TT. There is the change of structure of the words (the position) forming the phrase as shown on the numbered words in table 3 . This change is obligatory since the Indonesian language and English have different language structure otherwise the translation will be odd.

\section{Addition}

Addition frequently occurs in translation since most languages have different language structures. The addition is a translation strategy "in which something is added to the TT which is not present in the ST (Dickins, Hervey \& Higgins, 2002). In the translated sentence provided in table 3, the words the and of are added when translating the phrase kualitas hidup (ST) into 'the quality of life' (TT). The translator can adequately translate the phrase into life quality (by using transposition) and it still has the same meaning, yet the translator prefers to maintain the structure of the words forming the phrase by adding the words the and of in order to emphasize the relationship between 'quality' and 'life', thus the phrase sounds more natural. 


\section{Omission}

Omission also frequently occurs in translation due to different language structure. Omission is skipping words, phrases, clauses, sentences and even complete segments from the ST either intentionally or unintentionally. It is estimated to be " Strongly Domesticating; because no trace of the original is left in the TT" (Van Poucke, 2012). In the translated sentence provided in table 4, the omission of the word chronic in the translation of the phrase penyakit kronis lainnya (ST) into 'other diseases' (TT), gives the negative effect to the readers since the word omitted is an important message to be conveyed from that phrase. Therefore, the omission done by the translator, in this case, is considered inappropriate or misused as a distortion of the message occurs which may cause the loss of information. Further, it can affect the quality of the translation itself as well as the translator's competence or even it can be a representation of the translator's inattention or carelessness.

\section{CONCLUSION AND SUGGESTION}

Foreignization and domestication are significant translation strategies in the website localization of Ministry of Health of the Republic of Indonesia proved by all translation strategies under foreignization and domestication reference involved. The highest percentage of literal translation as one of domesticating translation strategies indicate the translator tries to maintain or keep the information of the source language. Further, the using of both strategies in translating the information in the selected news continuously implies that the relation between them is complimentary and should be unified. Thus, the effect of the translation will be much better.

\section{Acknowledgment}

The authors gratefully acknowledge that the present research is supported by the Ministry of Research and Technology and the Higher Education Republic of Indonesia. The support is under the research grant TALENTA USU of the Year 2019.

\section{REFERENCES}

Baawaidhan, A. G. (2016). Applying Foreignization and Domestication in Translating Arabic Dialectical Expressions into English. International Journal of Linguistics, 8(4), 197. https:/ / doi.org/10.5296/ijl.v8i4.9665

Cui, J. (2011). A study on the relativity of foreignization and domestication in translation based on data comparison. Communications in Computer and Information Science. https:/ / doi.org/10.1007/978-3-642-23339-5_64

Gutiérrez-Artacho, J., \& Olvera-Lobo, M. D. (2017). Web localization as an essential factor in the internationalisation of companies: An 
approximation of spanish SMEs. Advances in Intelligent Systems and Computing, 569, 511-520. https://doi.org/10.1007/978-3-319-56535-4_52 http://www.kemkes.go.id/

Nasution, E. H. (2015). Meaning equivalence in translation of proverbs. 15th International Conference on Translation (ICT15), (August), 443-450.

Obeidat, E., A., \& Abu-Melhim, A. (2017). Foreignization and Domestication in Translating English-Arabic Baby Formula Labels. British Journal of Humanities and Social Sciences.

Prasetyo, J., \& Nugroho, A. (2013). Domestication and Foreignization and Their Impacts To Translation. Language Circle: Journal of Language ..., VIII(October), 1-10. Retrieved from http:/ /journal.unnes.ac.id/nju/index.php/LC/article/view/3224

Sandrini, P. (2005). Website Localization and Translation. In H. GerzymischArbogast \& S. Nauert (Eds.), Challenges of Multidimensional Translation (EU High Le, pp. 131-138). Retrieved from http://www.translationconcepts.org/pdf/MuTra_2005_Proceedings.p df\#page $=5$

Sitohang, H. P. (2019). Translation Techniques in Official Australian Tourism Website.

Valdés, C. (2014). The localization of promotional discourse on the internet. https:/ / doi.org/10.1075/btl.78.23val

Venuti, L. (2008). The translator's invisibility: A history of translation (2nd ed.). New York, NY: Routledge.

Wang, F. (2014). An Approach to Domestication and Foreignization from the Angle of Cultural Factors Translation. Theory and Practice in Language Studies, 4(11). https:/ / doi.org/10.4304/tpls.4.11.2423-2427

Yang, L. (2014). The Application of Foreignization and Domestication in the Translation. https://doi.org/10.2991/icelaic-14.2014.81 